\title{
ANALYSIS OF ECJ CASE LAW ON DISCRIMINATORY TREATMENT OF CROSS-BORDER INHERITANCE TAX
}

\author{
Gracia Ma Luchena Mozo \\ University of Castilla-La Mancha, \\ International Centre for Financial Studies
}

\begin{abstract}
Recently, the European Commission has launched a package which deals with issues of double taxation and discriminatory tax treatment in the area of inheritance and estate tax. In the paper the Commission discusses ten cases in which the European Court of Justice examined the inheritance tax rules of Member States. In eight out of the ten cases it concluded that the Member States in question breached EU rules on the free movement of capital and/or freedom of establishment. For example, on the $3^{\text {rd }}$ of September 2014, the ECJ entered/made a judgment resolving that the Spanish Inheritance Tax should impose restrictions on the free movement of capital, one of the fundamental principles of the EU's Single Market. Taking into consideration the merits of the case the Court of Justice finally concluded that the situations between resident and non-resident taxpayers or between goods located in Spain or abroad are comparable and that therefore the applicable tax treatment should be the same.
\end{abstract}

Keywords: Inheritance and gift tax, Direct Taxation, Non-Residents, No Discrimination

\section{INTRODUCTION}

Judgements by the Court of Justice of the European Union (CJEU) on inheritance tax are relatively new. In fact, the EU until recently had no standard regulations on direct taxation and much less so on Inheritance and Gift Tax (IGT). In the absence of such regulations, IGT is a responsibility of individual EU Member States. All Member States shall, however, ensure to exercise the fundamental freedoms laid down by the EU legislation. This means that all Member States shall not draw a distinction between taxpayers on the basis of their nationality and should not restrict the fundamental freedoms arbitrarily. The CJEU confirmed that taxation on gifts and inheritances is subject to these freedoms. Nevertheless, the CJEU also declared that EU Member States are not liable to eliminate double taxation occurring as a result of their tax sovereignty.

The few number of Double Taxation Agreements on IGT makes the problem even more evident.

\section{INHERITANCE AND GIFT TAX IN JUDGEMENTS OF THE COURT OF JUSTICE OF THE EUROPEAN UNION}

As can be concluded from the analysis of the judgements of the CJEU in terms of inheritance taxation, the fundamental freedom set out by the Court judgements of 11 December 2003, Barbier (C-364/01, ECLI:EU:C:2003:665); in the Jäger Case (C-256/06, EU:C:2008:20); in the Halley 
case (C-132/10, ECLI:EU:C:2011:586) or in the Welte case (C-181/12, EU:C:2013:662) is the free movement of capital ${ }^{1}$. Nevertheless, judgements of 25 October 2007, Geurts and Vogten (C-464/05, ECLI:EU:C:2007:631) and of 9 July 2012, Scheunemann (C-31/11, ECLI:EU:C:2012:481), conclude that the type of freedom that is restricted is freedom of establishment, which concerns Member States themselves restrictively. The dividing line between the two types of freedom is delineated by the subject of the legislation under analysis, as the Court has provided in a number of judgements ${ }^{2}$. These circumstances make the freedom of establishment and the free movement of capital lex specialis to the general principle of non-discrimination stated in Article 18 TFEU.

As shown by previous studies ${ }^{3}$, the principle of non-discrimination is regarded as the negative formulation of the principle of equality ${ }^{4}$. Equality, as a universal fundamental principle, dignifies international relations ${ }^{5}$. Within the European Union framework, the principle of equality is set out in Article 18 TFEU - formerly Article 12 EC Treaty -, which establishes a specific formulation of equality $^{6}$ for each type of freedom securing the proper functioning of the common market ${ }^{7}$, ultimately guaranteed by the CJEU. The internal market has been taken as a reference by the CJEU as part of its harmonisation policy with a view to attaining the four Community freedoms, based on

1 Commission Staff Working Paper, Non-discriminatory inheritance tax system: principles drawn from EU case-law. SEC(2011) 1488 final, 3.

2 Judgements of 12 September 2006, CadburySchweppes and Cadbury Schweppes Overseas (C-196/04),ECLI:EU:C:2006:544, paragraphs 31 to 33; of 3 October 2006, Fidium Finanz (C-452/04), ECLI:EU:C:2006:631, paragraphs 34 and 44 to 49; of 12 December 2006, Test Claimants in Class IV of the ACT Group Litigation (C-374/04), ECLI:EU:C:2006:773, paragraphs 37 to 38; Test Claimants in the FII Group Litigation (C-446/04), ECLI:EU:C:2006:774, paragraph 36; and of 13 March 2007, Test Claimants in the Thin Cap Group Litigation (C-524/04), ECLI:EU:C:2007:161, paragraphs 26 to 34.

3 LUCHENA MOZO, G. M.: La justicia tributaria en la imposición directa española a la luz del derecho comunitario: algunas reflexiones. In: Revista Peruana de Derecho Tributario, Universidad de San Martín de Porres Tax Law Review, Year 3, Issue 13, 2009; LUCHENA MOZO, G. M.: El principio de no discriminación en la jurisprudencia del TJUE: incidencia en la imposición directa española. In: Rivista Italiana Di Diritto Pubblico Comunitario, Issues 3-4, 2010, pp. 945-998.

4 This view is also supported by GOGA, G.L.: The General Principle of non Discrimination and Equal Treatment in the Legislation and Jurisprudence of the Court of Justice of the European Union. In: Acta Universitatis Danubius, vol. 5, num. $1 / 2013,138$

5 As a fundamental principle of International Law, equality entails equal treatment as set out by Article 24 OECD Model Agreement, yet subject to a reciprocity clause. To this matter, see MARTÍN JIMÉNEZ, A.J., CALDERÓN CARRERO, J.M.: Imposición directa y no discriminación comunitaria. Madrid: Edersa, p. 15 and ff.; MIRANDA PÉREZ, A.: La no discriminación fiscal en los ámbitos internacional y comunitario. Barcelona: Bosch, p. 91 and ff.; MARTÍN JIMÉNEZ, A.J.: No discriminación. AA.VV. In: Convenios Fiscales Internacionales y Fiscalidad de la Unión Europea. CISS, Valencia, 2008, p. $523 \mathrm{ff}$

The principle of non-discrimination in terms of tax legislation was promptly acknowledged by the European Court of Human Rights in Darby v Sweden, (June 2016) DOI= http://hudoc.echr.coe.int/sites/eng/pages/search.aspx?i=00157642\#\{“itemid”:[“001-57642”].

See BARDINI, C.: The Ability to Pay in the European Market: An Impossible Sudoku for the ECJ. In: Intertax, 2010, issue 1, 38, 2; ATTARD, R.: The European Convention on Human Rights (ECHR), tax controversy and tax policy. In: EU direct tax news, 2011, Issue 41 January/February, 2; ERGEC, R.. Taxation and Property Rights under the European Convention on Human Rights. In: Intertax, issue 1, 39, 2011, p. 10.

6 As highlighted by GARCÍA PRATS (1998), the principle of non-discrimination should be interpreted in consideration of each type of freedom: "with regard to the free movement of services, goods and capital, it is a regulatory or administrative obstacle restricting services or goods from other Member States that is considered as discriminatory. By contrast, when it comes to free movement of workers, discrimination occurs by placing obstacles - be it positive or negative - , such as more restrictive or rigorous measures and denial of the advantages granted to nationals themselves, to workers from other Member States or migrant workers" (Cf. Imposición directa, no discriminación y derecho comunitario. Madrid: Tecnos, 1998, p. 42).

7 MABBETT, D.: A Rights Revolution in Europe?. Regulatory and judicial approaches to nondiscrimination in insurance. In: LEQS Paper 38/2011. DOI= http://www.lse.ac.uk/europeanInstitute/LEQS/LEQSPaper38.pdf 
the equality of treatment between nationals and non-nationals, and thus, on the principle of nondiscrimination on the grounds of nationality. The latter principle thus constitutes a fundamental value and right ${ }^{8}$.

This new legal and political scenario has provided all European citizens with a number of rights that constitute their set of legal assets, granting them the status of Citizens of the European Union? This status "constitutes the guarantee of belonging to a political community under the rule of law"10. This guarantee is in turn grounded in the values of freedom, democracy, and equality shared by all Member States with a pluralistic society and based on non-discrimination, tolerance, justice, solidarity and equality ${ }^{11}$, as stated in the current Charter of Fundamental Rights of the European Union of March $2010^{12}$.

However, "the Community notion of discrimination poses a problem to the general taxation system, which distinguishes between residents and non-residents, because this notion is alien to international tax law. From a general perspective, Member States discriminate between resident and non-resident taxpayers and place the two types in different schemes in order to meet a minimum tax revenue threshold, promote national savings, and attract foreign investors" ${ }^{13}$. In addition, it should not be forgotten that Double Taxation Agreements (DTAs) between Member States - which the former Article 220 of the EC Treaty encouraged to conclude - are based on the mutual granting of advantages between two States, advantages that, by definition, are only applicable to residents in the States concerned. As a consequence, the Court "has no other choice but to try to strike a happy medium, being aware that the elimination of DTAs is not possible and preventing tax discrimination from being detrimental to the proper functioning of the internal market"14.

Undoubtedly, direct tax harmonisation in the European Union is, to say the least, difficult to achieve, given the lack of consensus as to which is the most adequate regulation system ${ }^{15}$ that would

8 IGLESIAS CASAIS, J.M.: No discriminación fiscal y derecho de establecimiento en la Unión Europea. Navarra: Aranzadi, 2007, p. 37.

This view is also held by the European Union Agency for Fundamental Rights: Handbook on European non-discrimination law. Publications Office of the European Union, 2010.

9 Cf. JACOBS, F.G.: Citizenship of the European Union-A Legal Analysis. In: European Law Journal, 2007, Vol. 13, No. 5, 597; TRYFONIDOU, A.: Purely Internal Situations and Reverse Discrimination in a Citizens Europe: Time to "Reverse" Reverse Discrimination. DOI= http://www.um.edu.mt/europeanstudies/books/CD_MESA09/pdf/atryfonidou.pdf.

10 Second Report from the Commission on Citizenship of the Union (COM (97) 230 final.

11 The Boukhalfa judgement of 30 April 1996, (C-214/94), ECLI:EU:C:1996:174, lays the ground for the CJEU to determine the scope, ratione territori, of Community provisions on the free movement of persons, more specifically, on the prohibition of discrimination between nationals within the European Union. Contrary to the view that the scope of application of such provisions would be limited to territories of the Member States, the CJEU would extend the scope beyond these territories, addressing situations and circumstances outside the European Union. This way, the CJEU is underscoring the strictly imperative nature of the principle of non-discrimination on grounds of nationality. This principle will be applicable to all situations holding a connection with the Union, whether in- or outside the Community. See GARDEÑES SANTIAGO, M.: La imperatividad internacional del principio comunitario de no discriminación por razón de la nacionalidad. In: Revista de Instituciones Europeas, issue 3, 1996, p. $863 \mathrm{ff}$.

12 OJEC C 83 of 30 March 2010.

13 HINOJOSA MARTÍNEZ, L. M.: Reflexiones en torno al concepto de discriminación: los obstáculos fiscales a la libre circulación de personas en la CE. In: Revista de Derecho Comunitario Europeo vol. 1, issue 2, 1997, p. 514.

14 Ibid., p. 515.

15 This claim is also made by DAHLBERG (2007). Dahlberg writes that "what is special with the area of direct taxation in relation to the European Union is that there have so far been few acts of law decided upon by the Member States. There are a few directives, but they affect only fragments of the tax law of the Member States, albeit important fragments. Such 'positive integration' has proved difficult for the Member States to agree upon. In stark contrast, there are well over one hundred cases decided by or pending at the Court where measures of direct taxation are questioned in relation to the 
harmonise Member States' domestic tax legislations - with a special focus on the principles of tax equity - with the EU's fundamental principles. We are referring to the principle of non-discrimination in matters of income taxes ${ }^{16}$, provided by the CJEU at the judgement Commission v France - Avoir Fiscal on 28 January $1986^{17}$. This judgement gave rise to a long series of ensuing judgements on the prohibition of tax discrimination in matters of direct taxation and on limited tax obligation. The effects of this principle affect other tax regulations, such as Corporation Tax (CT) - more specifically, undercapitalisation (Article 20 of the Consolidated Version of the Spanish Law on Corporation Tax) ${ }^{18}$ and $\mathrm{R}+\mathrm{D}$ deduction (Article 35 of the Consolidated Version of the Spanish Law on Corporation $\operatorname{Tax}^{19}$ ) - , and recently, Inheritance and Gift Tax (IGT). IGT is affected by the overused equality of treatment (based on the principle of non-discrimination), resulting in decreased tax power of Member States ${ }^{20}$.

It should be noted that although direct taxation falls within the competence of individual Member States, the latter should also respect Community Law ${ }^{21}$, and particularly, the principle of nondiscrimination. This said, the rules regarding equal treatment forbid not only overt discrimination by reason of nationality but also all covert forms of discrimination which, by the application of other criteria of differentiation, lead in fact to the same result ${ }^{22}$.

Consequently, discrimination can arise only through the application of different rules to comparable situations or the application of the same rule to different situations ${ }^{23}$. To this rule we should add a fun-

fundamental freedoms of the EC Treaty. In the large majority of the decided cases the outcome has been that national tax laws have been found to be in breach of fundamental freedoms. This has been labelled "negative integration". Such integration is problematic. The complex solutions needed for the facilitation of cross-border movement also in the area of direct taxation require general Community measures like directives. The Court can only respond to the isolated questions put before it." (Cf. The European Court of Justice and direct taxation: a recent change of direction, in National Tax Policy in Europe. München: Springer Gmbh \& Co, 2007, p. 167).

16 According to GONZÁLEZ GARCÍA (2004), the role of the principle of non-discrimination has changed over time in the jurisprudence of the CJEU to the point of becoming "the main limit to the exclusive competence that Member States rely on in terms of national taxation [...] [Consequently] the effects of this principle may cause the foundations of Member States' taxation systems to fall apart" (Cf. Una aproximación al contenido de los conceptos de no discriminación y restricción en el Derecho Comunitario. In: Documentos, issue 8, 2004, p. 10).

For a similar view, see HERRERA MOLINA, P.: Los Convenios de Doble Imposición ante las libertades comunitarias (Análisis de la Jurisprudencia del TJCE). In: Fiscalidad internacional. CEF, Madrid, 2005, p. 1079-1080.

According to the Directive of the Committee of the Regions on Frontier workers: Assessment of the situation after 20 years of the internal market: problems and perspectives - the development of Community-wide social law should not be left mainly to the European Court of Justice, but should itself actively contribute to solving frontier worker problems (OECD C 43, of 18 Februar 2005).

17 Judgement of 28 January 1986, Commission v France Avoir Fiscal, (C-270/83), ECLI:EU:C:1986:37.

18 Judgements of 12 December 2002, Lankhorst-Hohorst, (C-324/00), ECLI:EU:C:2002:749; of 13 March 2007, Test Claimants in the Thin Cap Group Litigation, (C-524/04), ECLI:EU:C:2007:161.

19 Judgement of 13 March 2008, (C-248/06), ECLI:EU:C:2008:161, which orders Spain to modify its regulation by virtue of Law 4/2008 of 23 December, so that deduction of costs relating to research and development is equally favourable in respect of costs incurred in Spain, in any Member State of the EU or the EEA.

20 See, to that matter, the cited Judgement Manninen (C-319/02), paragraph 19.

Cf. also MASON, R.: Flunking the ECJ's Tax Discrimination Test. In: Columbia Journal of Transnational Law, vol. 46, 2007. DOI $=$ http://ssrn.com/abstract $=1025522$.

21 See judgements of 11 August 1995, Wielockx, (C-80/94), ECLI:EU:C:1995:271, paragraph 16; of 16 July 1998 ICI, (C-264/96), ECLI:EU:C:1998:370, paragraph 19; of 29 April 1999, Royal Bank of Scotland,(C-311/97), ECLI:EU:C:1999:216, paragraph 19; Manninen, (C-319/02), cited above, paragraph 19; of 6 March 2007, Meilicke and Others, (C-292/04), ECLI:EU:C:2007:132, paragraph 19; and of 24 May 2007, Holböck, (C-157/05), ECLI:EU:C:2007:297, paragraph 21.

22 Judgement of 14 February 1995, Schumacker, (C-279/93), ECLI:EU:C:1995:31, paragraph 26.

23 Cited-above judgements, Schumacker, (C-279/93), paragraph 30; of 29 April 1999, Royal Bank of Scotland, (C-311/97), paragraph 26; of 14 September 1999, Geschwind, (C-391/97), ECLI:EU:C:1999:409, paragraph 21; of 27 March 2007, Talotta, (C-383/05), ECLI:EU:C:2007:181, paragraph 18. 
damental provision set out by the Court in relation to Personal Income Tax. According to this provision, the situations of residents and of non-residents are not, as a rule, comparable since they are objectively different in terms of where the major part of their income is normally concentrated, their personal ability to pay tax as well as their personal and family circumstances ${ }^{24}$. Nevertheless, tax benefits granted only to residents of a Member State may constitute discrimination in the spirit of the Treaty if there is no objective difference between the situations of a non-resident and a resident that justifies different treatment in this regard ${ }^{25}$. The CJEU has not conducted a test of comparability in the Judgement under analysis, as it did not in the Judgement handed down on the Spain case (C-127/12). This means that the CJEU is implicitly dismissing any justification for a difference between the two types of taxpayer.

Until recently, there were no measures for harmonisation of EU legislation in direct taxation ${ }^{26}$, and even less so in IGT. In the absence of regulations, IGT falls within the competence of individual Member States. However, Member States should respect the fundamental freedoms enshrined in the EU Law, and thus, they may not discriminate by reason of nationality or restrict these freedoms arbitrarily. The terms discrimination and restriction on Community freedoms have co-occurred and been used interchangeably in CJEU Judgements ${ }^{27}$. This may be the reason why no test of comparability was conducted. The opposite argument would involve a need for the Court to set a criterion when to use a test of comparability in order to objectively deliver judgements. To our view, although the Schumacker test seems to be implicitly overridden in Welte ${ }^{28}$, it would be better off relying on a specific criterion in cross-border situations ${ }^{29}$.

The Court also holds that Member States are not obliged to eliminate double taxation arising from the exercise in parallel of their fiscal sovereignty ${ }^{30}$. The few number of DTAs on IGT $^{31}$ makes

24 Cited-above judgements, Schumacker, (C-279/93), paragraphs 31 to 34; Wielockx, (C-80/94), paragraph 18; of 27 June 1996, Asscher, (C-107/94), ECLI:EU:C:1996:251, paragraph 41; and Talotta, (C-383/05), paragraph 19.

25 Cited-above judgements, Schumacker, (C-279/93), paragraphs 36 to 38, Asscher, (C-107/94), paragraph 42; Talotta, (C383/05), paragraph 19; of 18 June 2007, Lakebrink and Peters-Lakebrinkde, (C-182/06), ECLI:EU:C:2007:452, paragraph 29; and of 16 October 2008, Renneberg, (C-527/06), ECLI:EU:C:2008:566, paragraph 60.

26 The OECD began to work on inheritance matters in 1963, producing a Draft Convention to address the issue of double taxation on inheritances. On 31 May 1966, the first Model Double Taxation Convention on Inheritance Tax came to light. It was back in 1982 that the current DTA (Double Taxation Agreement) was drafted. This DTA extends its scope of application to inter vivos gifts, which were not provided for in the 1966 Model (Article 2.1 OCDE 1982).

27 See DAFNOMILIS, V.: A Comprehensive Analysis of ECJ Case Law on Discriminatory Treatment of Cross-Border Inheritances - Part 1. In: European Taxation, vol. 55, issue 11, 2015, p. 506.

28 (C-181/12), EU:C:2013:662, paragraph 46.

29 In this line of argumentation, see DAFNOMILIS, V.: A Comprehensive Analysis of ECJ Case Law on Discriminatory Treatment of Cross-Border Inheritances - Part 2. In: European Taxation, vol. 55, issue 12, 2015, pp. 575-577.

30 Judgement of 12 February 2009, Block, (C-67/08), ECLI:EU:C:2009:92, paragraph 30.

31 This type of agreement is particularly uncommon, particularly when compared to agreements on income and wealth tax. In fact, Spain has so far signed only three DTAs on IGT, namely: Greece (6 March 1919), France (Official State Gazette of 7 January 1964), and Sweden (Official State Gazette of 16 January 1964). Moreover, these agreements are so old that the only settled case-law that they include in this regard is but a ruling settled by the Directorate General for Taxation (12 February 1990). For further details, see LUCHENA MOZO, G. M.: Las PYMES familiares en Europa: notas sobre su tratamiento fiscal. In: Noticias de la Unión Europea, issue 303, 2010, p. 138; and TRINXET LLORCA, S.: European Union Direct Taxes. UK: Asset Protection Publishing, 2010, p. 121-122.

DTAs on IGT signed by Italy are also very few. Moreover, Italy's domestic law sets out a provision for unilateral elimination of double taxation, provided for by Article 26(1)b from the Decree Law 346/1990. See ALTANA, E. - SILVESTRI, L.: L’imposta sulle successioni e donazioni nel Testo Milano: Unico, 1963, p. 14.

For DTAs on IGT signed by Member States, see Commission Recommendation regarding relief for double taxation of inheritances, COM (2011) 8819 final. Annex II, 12; and European Union 2015. Ways to tackle inheritance cross-border tax obstacles facing individuals within the EU. Luxembourg, p. 14. 
the problem even more evident ${ }^{32}$. This problem would be solved by developing a multilateral instrument, which was suggested for the first time at a symposium on transferring businesses organised by the European Union and held in Brussels on 29-30 January 1994. Considering the Convention on the elimination of double taxation in connection with the adjustment of profits of associated enterprises (90/436/EEC), the implementation of a multilateral instrument would not be totally unfamiliar to the EU. Moreover, a multilateral instrument would also be in line with the provisions laid down in Action 15 of the OECD Base Erosion and Profit Shifting (BEPS) Plan. In any case, the effectiveness of the instrument would be yet to be determined.

Given the significance of IGT and its impact on the effectiveness of Community freedoms, the Commission Staff ${ }^{33}$ paid special attention to IGT in cross-border situations in the Commission Recommendation regarding relieffor double taxation of inheritances ${ }^{34}$. Added to this is the Opinion of the European Economic and Social Committee on the 'Communication from the Commission to the European Parliament, the Council and the European Economic and Social Committee - Tackling cross-border inheritance tax obstacles within the $\mathrm{EU}^{35}$.

The Commission and the Economic and Social Committee argue that cross-border inheritance tax obstacles could be tackled without adopting an instrument that would harmonise Member States' regulations on cross-border inheritance tax ${ }^{36}$. This instrument would then also be subject to tax-related strategies of each Member State. An apparently more effective way to tackle obstacles involves interfacing Member States' national tax systems, thus reducing chances of double or multiple inheritance taxation ${ }^{37}$. By the same token, the Commission requires, by virtue of fundamental freedoms enshrined by Community Treaties, that Member States should refrain from levying IGT that discriminates against cross-border situations ${ }^{38}$.

See RUST, A.: The concept of residence in inheritance tax law. In: Residence of individuals under tax treaties and EC law. Amsterdam: IBFD, p. 85-103.

32 This claim is also made in CUESTA DOMÍNGUEZ, J. - CARMONA MENDOZA, P.: La eliminación de la doble imposición internacional en materia de sucesiones: un camino aún por recorrer. In: Revista Aranzadi, issue 11, BIB 2012, p. 361 . DOI= www.westlaw.es.

See also MAISTO, G.: The pursuit of harmonization regarding taxes on death and the international implications. In: Bulletin of International Taxation, 2011, vol. 65, issues 4-5, p. $253 \mathrm{ff}$.

33 SEC(2011) 1488 final, SEC(2011) 1489 final, and SEC(2011) 1490.

See $\operatorname{COM}(2010) 769$ and Commission Staff working paper SEC(2010) 1576.

34 COM (2011) 8819 final.

35 Opinion of the European Economic and Social Committee on the 'Communication from the Commission to the European Parliament, the Council and the European Economic and Social Committee - Tackling cross-border inheritance tax obstacles within the EU', COM(2011) 864 final] (2012/C 351/09).

36 This opinion does not seem to be expressed in the Report of the European Union Expert Group. 2015. Ways to tackle inheritance cross-border tax obstacles facing individuals within the EU, p. 23, where one of the conclusions read: "By far the better solution to the problems we have identified would be the adoption of an instrument of EU law. The recommendation which the Commission has already made could be made legally binding".

37 The Opinion of the European Economic and Social Committee on the 'Communication from the Commission to the European Parliament, the Council and the European Economic and Social Committee - Tackling cross-border inheritance tax obstacles within the EU' specifically comments that "the approach of merely providing recommendations for implementation by individual Members States may be viewed to be not sufficiently effective in practice - it is recognised that it is also desirable, as the Commission is proposing, for individual Member States to be encouraged, in an expeditious manner, to operate multiple taxation relief mechanisms in a more effective and flexible manner, while the Commission would observe developments over the next three years with a view of adopting a stronger stance through a Directive if so required".

38 See O’SHEA, T.: Belgian Inheritance Tax Rules Breach EU Law. In: Tax Notes International, issue 18, 2011, p. 217 and ff. 
Some CJEU Judgements addressing situations contrary to inheritance taxation systems pursuant to Community $\mathrm{Law}^{39}$ are the following:

a) Judgement of 11 December 2003, Barbier (C-364/01, ECLI:EU:C:2003:665), is one of the first to prosecute a case involving a Netherlands' provision, where certain assets of a deceased's estate situated in the Netherlands and liable to transfer duty are levied differently according to whether the deceased resided in the Netherlands or abroad at the time of death. The Court finds that, within the meaning of Directive 88/361, national provisions that determine the value of immovable property for assessment of inheritance tax liability based on the criterion of residence are a restriction to the free movement of capital.

b) In the Geurts and Vogten Case (C-464/05, ECLI:EU:C:2007:631), the CJEU found, as far as freedom of establishment is concerned, that discrimination arises when family companies are not allowed to deduct inheritance tax liabilities because the companies do not employ workers from the Member State at issue.

c) In the Jäger Case (C-256/06, EU:C:2008:20), the Court found that free movement of capital prohibits Member States to implement legislation that advantages assets situated in the Member State at issue with a particularly favourable assessment and partial exemption over assets situated in other Member States, which would be assessed on the basis of regulations following fair market value. The calculation of the tax is directly linked to the value of the assets included in the estate, with the result that there is objectively no difference in situation such as to justify unequal tax treatment so far as concerns the level of inheritance tax payable in relation to, respectively, an asset situated in Germany and an asset situated in another Member State. A situation such as that of Mr Jäger is therefore comparable to that of any other heir whose inheritance consists only of agricultural land and forestry situated in Germany bequeathed by a person domiciled in that State ${ }^{40}$.

d) In the Eckelkamp case (C-11/07, ECLI:EU:C:2008:489), 2008, free movement of capital is also taken as the fundamental criterion to lay down that the situation of a non-resident heir who acquires immovable property located in Belgium and the situation of a resident heir are comparable in relation with the rules governing the taxable amount of the inheritance $\operatorname{tax}^{41}$.

e) In the same vein, in the Judgement of 11 September 2008, Arens-Sikken case (C-43/07, ECLI:EU:C:2008:490), the Court held that the rules of a Member State are contrary to EU Law if an heir is allowed to deduct debts by reason of inheritance solely when the heir is residing in the Member State where the property is situated ${ }^{42}$.

39 This was not the case for the cited-above Judgement, Van Hilten-Van der Heijden, (C-513/03), of 18 December 2014, Q, (C-133/13), ECLI:EU:C:2014:2460.

In this Sentence, the CJEU "holds, in relation to inheritance tax, that the fact that the grant of tax advantages is made subject to the condition that the asset transferred be situated in the national territory constitutes a restriction on the free movement of capital prohibited, in principle, by Article 63(1) TFEU (paragraph 20)". This decision applies save "the difference in treatment relates to situations which are not objectively comparable, such comparability being required to be assessed on the basis of the object and content of the national provisions at issue in the main proceedings" (paragraph 22). Precisely, this is mentioned in the main proceedings, given that "the object of the exemption from gift tax provided for by the Netherlands rules at issue in the main proceedings is to protect the integrity of the estates that are typical of the traditional Netherlands landscape" (paragraph 24).

See BROEK, J.J. VAN DEN - WILDEBOER, M.R.: European Court of Justice permits inheritance tax based on nationality in Van Hilten-Van der Heijden. In: Bulletin for International Taxation, vol. 61, issue 5, 2007, pp. 214-219.

Paragraph 44

41 Paragraphs 61 and 63.

42 Paragraph 46. 
f) The Court also held that a provision on inheritance and gift tax in the Mattner case (C-510/08, EU:C:2010:216), where the allowance to be set against the taxable value in the case of a gift of immovable property in the State at issue is smaller where the donor and the donee are resident in another Member State than the deduction which would have applied if at least one of them had been resident in the Member State at issue, is incompatible with the free movement of capital ${ }^{43}$.

g) In the Halley case (C-132/10, ECLI:EU:C:2011:586), the Court found it discriminatory that in matters of inheritance tax, a Member State provides for a limitation period for the valuation of registered shares which differs according to whether or not the centre of effective management of the company in which the deceased was a shareholder is situated in the Member State at issue. The Court held that a restriction on the exercise of free movement of capital cannot be justified ${ }^{44}$, on the grounds that the application of a limitation period of 10 years is not based on the time needed by the tax authorities of the Member State to have effective recourse to mechanisms of mutual assistance between Member States or other alternative means of investigating the value of the shares in question.

h) In the Scheunemann case (C-31/11, ECLI:EU:C:2012:481), the Court held that legislation of a Member State which, for the purposes of the calculation of inheritance tax, excludes the application of certain tax advantages to an estate in the form of a shareholding in a capital company established in a third country, while conferring those advantages in the event of the inheritance of such a shareholding when the registered office of the company is in a Member State, primarily affects the exercise of the freedom of establishment for the purposes of Article 49 TFEU et seq., since that holding enables the shareholder to exert a definite influence over the decisions of that company and to determine its activities. Those Treaty provisions are not intended to apply to a situation concerning a shareholding held in a company which has its registered office in a third country ${ }^{45}$.

i) The Court's Judgement in Welte (C-181/12, EU:C:2013:662) holds that "as regards inheritances, the measures which Article 56(1) EC prohibits as being restrictions on the movement of capital include those whose effect is to reduce the value of the inheritance of a resident of a State other than the State in which the assets concerned are situated and which taxes the inheritance of those assets ${ }^{46}$. In other words, and most importantly, "the situations of those subject to inheritance tax, be resident or non-resident, are wholly comparable, although a resident heir is taxed on all of the assets acquired, whereas a non-resident heir is only taxed on the assets situated in the Member State levying $\operatorname{tax}^{47}$.

j) Judgement of 4 September 2014 (C-211/13, EU:C:2014:2148) was delivered following the infringement proceedings against Germany because of derogation of the Inheritance and Gift Tax Scheme (Erbschaftsteuer-und Schenkungsteuergesetz - ErbStG-), which provides that tax is solely

43 See O'SHEA, T.: News Analysis: No Excuses for German Gift Tax Rule. In: Tax Notes International, issue 28, 2010, pp. 1021 ff.; VICENTE-ARCHE COLOMA, P.: El Impuesto sobre Donaciones y la libre circulación de capitales a la luz de la Sentencia Mattner, de 22 de abril de 2010 (C-510/08). In: Noticias de la Unión Europea, issue 330, 2012, p. 139.

44 See O'SHEA, T.: Belgian Inheritance Tax Rules Successfully Challenged Before the ECJ. In: Tax Analysts, issue 5, 2011, p. $721 \mathrm{ff}$.

45 O'SHEA, T.: German Inheritance Tax Rules Upheld by the ECJ. In: Tax Notes International, issue 15, 2012, p. 289 ff.

46 Welte Judgement, (C-181/12), cited above, paragraph 23.

47 WATTEL, P. J.: Progressive Taxation of Non-Residents and Intra-EC Allocation of Personal Tax Allowances: Why Schumacker, Gilly and Gschwind do not suce. In: European Taxation, Volume 40, issue 6, 2000, pp. 227-228; HERRERA MOLINA, P.M.: STJUE WELTE: ¿El fin de las reducciones y beneficios fiscales autonómicos en el Impuesto sobre Sucesiones? In: ECJ leading cases, Tributos, gasto público y la crisis del Estado de Derecho, 2015. https://ecjleadingcases. wordpress.com/?s=+WELTE. 
levied on immovable property situated in Germany. Under this scheme, a significantly lower allowance is applicable if the donor or deceased person and the recipient of the inheritance or gift are non-residents at the time of the succession or donation, in contrast to a situation where at least one of them resides in Germany. This applies despite the legislative amendment made to the Inheritance and Gift Tax Scheme in 2011 following the judgment in Mattner (C-510/08, EU:C:2010:216), where non-residents are granted the possibility to be treated, upon request, in Germany as tax residents for the purposes of gift and inheritance tax. However, this option does not, in view of the Commission, eliminate the infringement ${ }^{48}$.

k) Judgement of 4 September 2014 was delivered following the infringement proceedings against Spain (C-127/12, EU:C:2014:2130) ${ }^{49}$. The Court finds that Spain does not comply with the obligations laid down by TFUE in permitting different succession and donation tax treatments between resident and non-resident successors and donees in Spain, between deceased persons residing and not residing in Spain and between donations and similar arrangements of immovable property located inside and outside Spain.

1) Judgment of the Court of 16 July 2015 (C-485/14, ECLI:EU:C:2015:506). According to the Commission, the Court declares that, French legislation, as interpreted by the tax authorities, exempts from droits de mutation à titre gratuit gifts and legacies to public bodies or to charitable bodies only where such bodies are established in France, in a Member State or in a State which is party to the Agreement on the European Economic Area which has concluded a bilateral agreement with France. The Commission considers that that constitutes a restriction on free movement of capital, contrary to Article $56 \mathrm{EC}$ and Article 40 of the EEA Agreement.

Based on the abovementioned rulings, TFEU holds that free movement of capital is restricted in the following cases:

- If the value of an inheritance or gift is reduced as a result of a higher tax burden on the acquirer who resides in a Member State other than that of the deceased or donor ${ }^{50}$;

- If non-residents are treated more favourably ${ }^{51}$;

- In case of restriction on deductibility of liabilities linked to inheritance assets ${ }^{52}$;

- If resident taxpayers are granted higher personal allowances than non-resident taxpayers ${ }^{53}$.

48 IP/12/1018, http://europa.eu/rapid/press-release_IP-12-1018_de.htm.

It could not be otherwise after Judgement of 18 March 2010, Gielen, (C-440/08), ECLI: EU:C:2010:148, where the Court holds that the possibility granted to non-residents does not eliminate the infringement.

49 LUCHENA MOZO, G. M.: La definitiva configuración del estatuto del no residente comunitario en la imposición directa tras la sentencia de 3 de septiembre de 2014, Comisión/España, (C-127/12). In: Rivista di Diritto Tributario Internazionale, 3/2013; ROVIRA FERRER, I.: The taxation of gratuitous transfers between immediate family members: an analysis of the Spanish perspective. In: European Taxation, vol. 55, issue 8, 2015, p. 385.

50 See abovementioned Judgements Jäger, (C-256/06), paragraph 31, and Mattner, (C-510/08), paragraph 25.

See also GARCÍA DE PABLOS, J. F.: Impuesto sobre Sucesiones y Donaciones en España: la necesaria reforma a la luz de la jurisprudencia del TJUE. In: Quincena Fiscal, issue 17, BIB 2010, 1975. DOI= www.westlaw.es; LUCAS DURÁN, M.: Fiscalidad y libre circulación de capitales y pagos en el Derecho de la Unión Europea: análisis jurisprudencial. In: Documentos de Trabajo UC-CIFF-IELAT, issue 8, 2012. DOI= http://www.ciff.net/attachments/publicaciondtc8.pdf; CALVO VÉRGEZ, J.: La aplicación del Impuesto sobre Sucesiones y Donaciones a los no residentes a la luz de los últimos pronunciamientos de la Comisión Europea. In: Quincena Fiscal, issue 11, BIB 2013, p. 1177. DOI= www.westlaw.es.

51 As found in the abovementioned Judgement Van Hilten-Van der Heijden, (C-513/03), paragraph 41.

52 See COPENHAGEN ECONOMICS. Study on Inheritance Taxes in EU Member States and Possible Mechanisms to Resolve Problems of Double Inheritance Taxation in the EU, August 2010, p. 7.

53 See, to that matter, Judgements of 4 September 2014, Commission/Germany (C-211/13) and Commission/Spain (C127/12), cited above. 
This all applies in the understanding that the existence of an option which would possibly render a situation compatible with EU law does not, in itself, correct the unlawful nature of a system which still includes a mechanism of taxation that is not compatible with that law ${ }^{54}$. This is referred to by the CJEU in Judgement of 8 June 2016, Hünnebeck, (C-479/14, ECLI:EU:C:2016:412), paragraph 42 .

As a result of the above, many Member States still have great difficulty making their domestic tax regimes entirely compatible with rules on free movement of capital laid down by the Treaty ${ }^{55}$. Evidence can be found in the number of procedures undertaken by the Commission in relation to a variety of inheritance tax regulations in different Member States, as documented in this paper. It should also be noted that the majority of Member States have an inheritance tax regime, which normally takes place of residence as the criterion for inheritance tax assessment ${ }^{56}$. However, the CJEU does not legitimise any tax rules that establish a difference in treatment between taxpayers based on their place of residence ${ }^{57}$, but such a difference in treatment must concern situations which are not objectively comparable or be justified by overriding reasons in the general interest ${ }^{58}$. In the case at issue, the Court held that "a national tax legislation which, for the purposes of calculating inheritance tax, treats residents and non-residents or assets situated inside and outside the Member State concerned on the same footing cannot, without being discriminatory, treat the two categories of taxpayer or asset unequally as far tax reduction is concerned ${ }^{59}$. It then follows that there is no objective difference between the two taxpayer models justifying unequal tax treatment. This general statement was also sufficient for the CJEU to find a breach of the Treaty Law in its Judgement of 3 September 2014, Commission/Spain, (C-127/12). Thus no effective comparability analysis was necessary to be conducted, but it would have been highly advisable, given the singularities of the Spanish legal regime ${ }^{60}$. Conducting the analysis would also be positive because it would raise the question whether or not the test of comparability and the justification of the measure overlap ${ }^{61}$.

54 See the Court's ruling in Judgement of 18 March 2010, Gielen, (C-440/08), cited above, where the Court declares that the possibility granted to non-residents excludes any validatory effects, since it would involve opting for a discriminatory or non-discriminatory regime. Arguing otherwise would mean "validating a tax regime which, in itself, remains contrary to Article 49 TFEU by reason of its discriminatory nature" (paragraph 52). It thus follows that "the choice offered, in the dispute in the main proceedings, to non-resident taxable persons by means of the option to be treated as resident taxable persons does not serve to neutralise the discrimination established in paragraph 48 above" (paragraph 54).

55 COPENHAGEN ECONOMICS. Study on Inheritance Taxes in EU Member States and Possible Mechanisms to Resolve Problems of Double Inheritance Taxation in the EU, pp. 7 and 33.

See also MOLL, H. - RAVENTÓS CALVO, S.: Case Study: On possible double taxation and other problems affecting the Free Movement of Persons and Capital within Europe resulting from Inheritance tax, illustrated by the example Gemany/ Sapin. In: European Taxation, Volume 45, 2005, issue 9/10, pp. 452-460.

56 Belgium, Czech Republic, Denmark, Finland, Germany, Hungary, Ireland, Italy, Lithuania, Luxemburg, The Netherlands, Poland, Slovenia, and Spain are the Member States in the EU that take residence as a criterion for inheritance tax assessment.

See also COPENHAGEN ECONOMICS. Study on Inheritance Taxes in EU Member States and Possible Mechanisms to Resolve Problems of Double Inheritance Taxation in the EU, p. 21.

57 See GARCÍA DE PABLOS, J. F.: La urgente reforma del Impuesto sobre Sucesiones y Donaciones en España a la luz del Derecho comunitario. In: Quincena Fiscal, issue 18, BIB 2014, p. 3507. DOI= www.westlaw.es.

58 See abovementioned Judgement Arens-Sikken, (C-43/07), paragrah 53.

59 See abovementioned Judgement of 26 May 2016, Commission/Hellenic Republic, paragraph 36.

60 GARCÍA PRATS, F.A.: El Derecho de la unión Europea ante la encrucijada del Impuesto sobre Sucesiones y Donaciones español. In: Revista Española de Derecho Financiero, issue 164, 2014, pp. 33-34.

61 See WATTEL, P.: Non-Discrimination à la Cour: The ECJ's (Lack of) Comparability Analysis in Direct Tax Cases. In: European Taxation, vol. 55, 2015, issue 12, p. 542. 
However, as highlighted above, inheritance tax obstacles do not exclusively arise from discrimination found in domestic legislation systems between cross-border and national-only situations, but also from risk of double taxation. For this reason, the Commission has opted for a flexible approach to the matter, promoting coordination between national law regimes in entire compliance with rules on tax policy ${ }^{62}$. However, it is yet to be determined if the Commission's initiative demonstrates effective in the tax regimes of Member States ${ }^{63}$.

\section{CONCLUSIONS}

This paper calls for the need to stay informed about upcoming rulings issued by the CJEU on IGT in its process of adaptation to and regularisation in Community Law, rulings that will certainly continue to be issued in the future. Since direct taxation is still the responsibility of Member States, it is Member States that tackle problems caused by management of this taxation at Community level. However, action by the EU seems to be justified not only because of inaction of Member States themselves, but also because of the impact that this inaction has on the interior market. This impact is precisely what justifies EU action. Union action, which departs from harmonisation, shall respect the principle of proportionality (as laid down by Article 5 TEU9), but it shall have a bearing on Member States' legislation systems. The problem emerges in the way Community Law may/ should have an influence on Member States' legal regulations ${ }^{64}$. In this regard, risk comes from finding obstacles to the normal functioning of the interior market in matters of taxation as a potential reason for the Union to consider that any national tax measures affecting national and cross-border situations are contrary to Community Law, unless the Court considers that there is justification for those measures to be taken.

\section{Bibliography:}

ALTANA, E. - SILVESTRI, L.: L’imposta sulle successioni e donazioni nel Testo Unico. Milano, 1963.

ATTARD, R.: The European Convention on Human Rights (ECHR), tax controversy and tax policy. In: EU direct tax news, Issue 41, 2011.

BARDINI, C.: The Ability to Pay in the European Market: An Impossible Sudoku for the ECJ. In: Intertax, issue 1, $38,2010$.

62 Opinion of the European Economic and Social Committee on "Communication from the Commission to the European Parliament, the Council and the European Economic and Social Committee - Tackling cross-border inheritance tax obstacles within the EU", COM(2011) 864 final.

63 See NAVEZ, E.J.: The Influence of EU Law on Inheritance Taxation: Is the Intensification of Negative Integration Enough to Eliminate Obstacles Preventing EU Citizens from Crossing Borders within the Single Market? In: EC Tax Review, vol. 21, issue 2, 2012, p. 93.

See also CUESTA DOMIÍNGUEZ, J. - CARMONA MENDOZA, P.: La eliminación de la doble imposición internacional en materia de sucesiones: un camino aún por recorrer. In: Revista Aranzadi, issue 11, 2011, pp. 59-70; MARTÍN ROMAN, J. - DEL BLANCO GARCÍA, A. La problemática de las sucesiones transfronterizas en Europa. In: Crónica Tributaria, issue 151, 2014, p. 130.

64 The Report of the European Union Expert Group. Ways to tackle inheritance cross-border tax obstacles facing individuals within the EU, 2015, p. 19, reads: "although the recommendation has been ignored by Member States, it has not been met with strong expressions of hostility. It would, therefore, be reasonable for the European Commission to propose that the terms of the recommendation be turned into a regulation". 
BROEK, J.J. VAN DEN - WILDEBOER, M.R.: European Court of Justice permits inheritance tax based on nationality in Van Hilten-Van der Heijden. Bulletin for International Taxation, Volume 61, issue 5, 2007.

CALVO VÉRGEZ, J.: La aplicación del Impuesto sobre Sucesiones y Donaciones a los no residentes a la luz de los últimos pronunciamientos de la Comisión Europea. Quincena Fiscal, issue 11. BIB 2013, p. 1177. DOI= www. westlaw.es.

CUESTA DOMIÍNGUEZ, J. - CARMONA MENDOZA, P.: La eliminación de la doble imposición internacional en materia de sucesiones: un camino aún por recorrer. In: Revista Aranzadi, issue 11, 2011.

CUESTA DOMIÍNGUEZ, J. - CARMONA MENDOZA, P.: La eliminación de la doble imposición internacional en materia de sucesiones: un camino aún por recorrer. In: Revista Aranzadi, issue 11. BIB 2012, p. 361. DOI= www. westlaw.es.

DAFNOMILIS, V.: A Comprehensive Analysis of ECJ Case Law on Discriminatory Treatment of Cross-Border Inheritances - Part 1. In: European Taxation, vol. 55, issue 11, 2015.

DAFNOMILIS, V.: A Comprehensive Analysis of ECJ Case Law on Discriminatory Treatment of Cross-Border Inheritances - Part 2. In: European Taxation, vol. 55, issue 12, 2015.

DAHLBERG: The European Court of Justice and direct taxation: a recent change of direction, in National Tax Policy in Europe. München: Springer Gmbh \& Co, 2007

ERGEC, R.: Taxation and Property Rights under the European Convention on Human Rights. In: Intertax, Issue 1, 2011 , p. 39.

GARCÍA DE PABLOS, J. F.: Impuesto sobre Sucesiones y Donaciones en España: la necesaria reforma a la luz de la jurisprudencia del TJUE. In: Quincena Fiscal, issue 17, BIB 2010, 1975. DOI= www.westlaw.es.

GARCÍA DE PABLOS, J. F.: La urgente reforma del Impuesto sobre Sucesiones y Donaciones en España a la luz del Derecho comunitario. In: Quincena Fiscal, issue 18, BIB 2014, p. 3507. DOI= www.westlaw.es

GARCÍA PRATS, F. A.: Imposición directa, no discriminación y derecho comunitario. Madrid: Tecnos, 1998.

GARCÍA PRATS, F. A.: El Derecho de la unión Europea ante la encrucijada del Impuesto sobre Sucesiones y Donaciones español. In: Revista Española de Derecho Financiero, issue 164, 2014.

GARDEÑES SANTIAGO, M.: La imperatividad internacional del principio comunitario de no discriminación por razón de la nacionalidad. In: Revista de Instituciones Europeas, issue 3, 1996.

GOGA, G. L.: 2003. The General Principle of non Discrimination and Equal Treatment in the Legislation and Jurisprudence of the Court of Justice of the European Union. In: Acta Universitatis Danubius, vol. 5, núm. 1/2013.

GONZÁLEZ GARCÍA: Una aproximación al contenido de los conceptos de no discriminación y restricción en el Derecho Comunitario. In: Documentos, issue 8, 2004.

HERRERA MOLINA, P.: Los Convenios de Doble Imposición ante las libertades comunitarias (Análisis de la Jurisprudencia del TJCE). In: Fiscalidad internacional. Madrid: CEF, 2005.

HERRERA MOLINA, P.: STJUE WELTE: ¿El fin de las reducciones y beneficios fiscales autonómicos en el Impuesto sobre Sucesiones?. ECJ leading cases, Tributos, gasto público y la crisis del Estado de Derecho, 2015. https:// ecjleadingcases.wordpress.com/?s=+WELTE

HINOJOSA MARTÍNEZ, L. M.: Reflexiones en torno al concepto de discriminación: los obstáculos fiscales a la libre circulación de personas en la CE. In: Revista de Derecho Comunitario Europeo, vol. 1, issue 2, 1997.

IGLESIAS CASAIS, J. M.: No discriminación fiscal y derecho de establecimiento en la Unión Europea. Navarra: Aranzadi, 2007.

JACOBS, F. G.: Citizenship of the European Union-A Legal Analysis. In: European Law Journal, Vol. 13, No. 5, 2007.

LUCAS DURÁN, M.: Fiscalidad y libre circulación de capitales y pagos en el Derecho de la Unión Europea: análisis jurisprudencial. In: Documentos de Trabajo UC-CIFF-IELAT, issue 8, 2012. DOI= http://www.ciff.net/attachments/publicaciondtc8.pdf.

LUCHENA MOZO, G. M.: La justicia tributaria en la imposición directa española a la luz del derecho comunitario: algunas reflexiones. In: Revista Peruana de Derecho Tributario, Universidad de San Martín de Porres Tax Law Review, Year 3, Issue 13, 2009. 
LUCHENA MOZO, G. M.: El principio de no discriminación en la jurisprudencia del TJUE: incidencia en la imposición directa española. In: Rivista Italiana Di Diritto Pubblico Comunitario, Issues 3-4, 2010.

LUCHENA MOZO, G. M.: Las PYMES familiares en Europa: notas sobre su tratamiento fiscal. In: Noticias de la Unión Europea, issue 303, 2010.

LUCHENA MOZO, G. M.: La definitiva configuración del estatuto del no residente comunitario en la imposición directa tras la sentencia de 3 de septiembre de 2014, Comisión/España, (C-127/12). In: Rivista di Diritto Tributario Internazionale, $3 / 2013$.

MABBETT, D.: A Rights Revolution in Europe?. Regulatory and judicial approaches to nondiscrimination in insurance. LEQS Paper 38/2011. DOI= http://www.lse.ac.uk/europeanInstitute/LEQS/LEQSPaper38.pdf

MAISTO, G.: The pursuit of harmonization regarding taxes on death and the international implications. Bulletin of International Taxation, 2011, vol. 65, issues 4-5.

MARTÍN JIMÉNEZ, A. J.: No discriminación. In: Convenios Fiscales Internacionales y Fiscalidad de la Unión Europea. Valencia: CISS, 2008.

MARTÍN JIMÉNEZ, A.J. - CALDERÓN CARRERO, J.M. Imposición directa y no discriminación comunitaria. Madrid: Edersa, 2000.

MARTÍN ROMAN, J. - DEL BLANCO GARCÍA, A.: La problemática de las sucesiones transfronterizas en Europa. In: Crónica Tributaria, issue 151, 2014.

MASON, R.: Flunking the ECJ's Tax Discrimination Test. In: Columbia Journal of Transnational Law, Vol. 46, 2007. DOI= http://ssrn.com/abstract $=1025522$

MIRANDA PÉREZ, A.: La no discriminación fiscal en los ámbitos internacional y comunitario. Barcelona: Bosch, 2005.

MOLL, H. - RAVENTÓS CALVO, S.: Case Study: On possible double taxation and other problems affecting the Free Movement of Persons and Capital within Europe resulting from Inheritance tax, illustrated by the example Gemany/Sapin. In: European Taxation, 2005, vol. 45, issue 9/10.

NAVEZ, E.J.: The Influence of EU Law on Inheritance Taxation: Is the Intensification of Negative Integration Enough to Eliminate Obstacles Preventing EU Citizens from Crossing Borders within the Single Market? In: EC Tax Review, vol. 21, issue 2, 2012.

O'SHEA, T.: News Analysis: No Excuses for German Gift Tax Rule. In: Tax Notes International, issue 28, 2010.

O'SHEA, T.: Belgian Inheritance Tax Rules Breach EU Law. In: Tax Notes International, issue 18, 2011.

O'SHEA, T.: Belgian Inheritance Tax Rules Successfully Challenged Before the ECJ. In: Tax Analysts, issue 5, 2011.

O'SHEA, T.: German Inheritance Tax Rules Upheld by the ECJ. In: Tax Notes International, issue 15, 2012.

ROVIRA FERRER, I.: The taxation of gratuitous transfers between immediate family members: an analysis of the Spanish perspective. In: European Taxation, vol. 55, issue 8, 2015.

RUST, A.: The concept of residence in inheritance tax law. In: Residence of individuals under tax treaties and EC law. Amsterdam: IBD, 2010.

TRINXET LLORCA, S.: European Union Direct Taxes. UK: Asset Protection Publishing, 2010.

TRYFONIDOU, A.: Purely Internal Situations and Reverse Discrimination in a Citizens Europe: Time to "Reverse" Reverse Discrimination, 2016. DOI= http://www.um.edu.mt/europeanstudies/books/CD_MESA09/pdf/atryfonidou.pdf.

VICENTE-ARCHE COLOMA, P.: El Impuesto sobre Donaciones y la libre circulación de capitales a la luz de la Sentencia Mattner, de 22 de abril de 2010 (C-510/08). In: Noticias de la Unión Europea, issue 330, 2012.

WATTEL, P. J.: Progressive Taxation of Non-Residents and Intra-EC Allocation of Personal Tax Allowances: Why Schumacker, Gilly and Gschwind do not suce. In: European Taxation, vol. 40, issue 6, 2000.

WATTEL, P. J.: Non-Discrimination à la Cour: The ECJ's (Lack of) Comparability Analysis in Direct Tax Cases. In: European Taxation, Volume 55, issue 12, 2015. 


\section{Contact information:}

Gracia M. Luchena Mozo

Full Professor Tax Law, International Centre for Financial Studies

Gracia.Luchena@uclm.es

University of Castilla-La Mancha (Spain)

Plaza de la Universidad 1, 02071, Albacete. Spain.

Telephone: 0034967599200, ext. 2317 